\title{
Mesenchymal stem cells exert anti-proliferative effect on lipopolysaccharide-stimulated BV2 microglia by reducing tumour necrosis factor-a levels
}

Shinsmon Jose ${ }^{1,2,3}$, Shi Wei Tan ${ }^{1}$, Yin Yin Ooi ${ }^{4}$, Rajesh Ramasamy ${ }^{2,5}$ and Sharmili Vidyadaran ${ }^{1,2^{*}}$

\begin{abstract}
Background: Progression of neurodegenerative diseases occurs when microglia, upon persistent activation, perpetuate a cycle of damage in the central nervous system. Use of mesenchymal stem cells (MSC) has been suggested as an approach to manage microglia activation based on their immunomodulatory functions. In the present study, we describe the mechanism through which bone marrow-derived MSC modulate the proliferative responses of lipopolysaccharide-stimulated BV2 microglia.
\end{abstract}

Methods: BV2 microglia were cultured with MSC and stimulated with $1 \mu \mathrm{g} / \mathrm{ml}$ lipopolysaccharide. Using an inducible nitric oxide synthase inhibitor, tritiated thymidine ( $\left.{ }^{3} \mathrm{H}-\mathrm{TdR}\right)$ incorporation assay was performed to determine the role of nitric oxide in the anti-proliferative effect of MSC. We also studied apoptosis and the cell cycle of both cell types using flow cytometry and explored their cytokine profile using protein and cytometric arrays. Moreover, the role of IL-6 and TNF-a in immunomodulation was deduced using specific blocking antibodies and recombinant proteins.

Results: MSC reduces microglia proliferation upon lipopolysaccharide stimulation by 21 to $28 \%$ and modulates the levels of nitric oxide, IL-6 and TNF- $a$. The role of nitric oxide in conferring the anti-proliferative effect of MSC was ruled out. Furthermore, we found that MSC exert their anti-proliferative effect by restoring the percentage of BV2 cells at S and G2/M phase to levels similar to unstimulated cells. MSC undergo a G0/G1 arrest while exerting this effect. We have also identified that MSC-mediated modulation of microglia is independent of IL-6, whilst reduction of TNF-a in co-culture is critical for inhibition of microglia proliferation.

Conclusions: Our study demonstrates that MSC inhibit microglia proliferation independent of nitric oxide and IL-6, although reduction of TNF-a is critical for this effect. The inhibition of proliferation is through cell cycle modulation. These findings shed light on the mechanisms of microglial immunomodulation by MSC.

Keywords: Microglia, Mesenchymal stem cells, Nitric oxide, Cell cycle, Interleukin-6, Tumour necrosis factor-a

\footnotetext{
* Correspondence: sharmili@upm.edu.my

'Neuroinflammation Group, Immunology Laboratory, Department of

Pathology, Faculty of Medicine and Health Sciences, Universiti Putra Malaysia,

43400 Serdang, Selangor, Malaysia

${ }^{2}$ Genetic Medicine Research Centre, Faculty of Medicine and Health Sciences,

Universiti Putra Malaysia, 43400 Serdang, Selangor, Malaysia

Full list of author information is available at the end of the article
} 


\section{Background}

Mesenchymal stem cells (MSC) are a group of clonogenic, non-haematopoietic, plastic adherent multi-potent stromal cells that possess potential to differentiate into cells of mesodermal lineage [1,2]. MSC have been shown to ameliorate disease in numerous clinical trials and animal models. Approximately 400 clinical trials using MSC are currently underway according to the clinical trials registry of the US National Institute of Health (http://clinicaltrials. gov). It is noteworthy that a good proportion of these studies are exploring the immunomodulatory properties of MSC. This aspect of MSC is widely explored in managing graft-versus-host disease [3] and in a variety of experimental disease models, including autoimmune encephalomyelitis [4], stroke [5], amyotrophic lateral sclerosis [6], spinal cord injury [7], diabetes [8] and myocardial infarction [9]. These advances at the therapeutic level are a result of detailed descriptions on the potential of MSC to modulate a range of immune cells including $\mathrm{T}$ cells, $\mathrm{B}$ cells, dendritic cells, monocytes and macrophages [10-15].

Microglia are resident macrophages of the central nervous system (CNS), derived from primitive myeloid progenitors that migrate from the embryonic yolk sac to the brain rudiment [16]. In adults, microglia survey the entire brain every couple of hours through concerted movements [17] for damaged neurons, endogenous disease proteins, and infection [18]. Microglia assume functions beyond being immune sentinels by maintaining a healthy CNS environment through synaptic pruning [19-21] and secretion of neurotrophic factors [22,23]. In response to disturbances in CNS homeostasis microglia undergo morphological, phenotypic and functional changes. These changes include an increase in numbers through proliferation, a shift from ramified to amoeboid morphology, secretion of inflammatory mediators such as cytokines, chemokines and reactive oxygen and nitrogen species, and an increase in phagocytic activity. Experiments have shown that these changes which microglia undergo upon activation can cause deleterious effects within the CNS microenvironment and play a key role in pathogenesis of neurodegenerative disease [24-27].

Modulating microglia responses is being considered as an effective approach to manage progression of neurodegenerative diseases. Recently, with the rise in reports on immunomodulatory prospects of MSC, we and others have explored and described the potential of MSC to dampen inflammatory responses of microglia [28-32]. However, the mechanisms underlying these effects are poorly understood. The present study determined the mechanisms through which MSC confer an anti-proliferative effect on microglia by examining apoptosis and cell cycle. We also determined the role of nitric oxide, IL- 6 and TNF- $\alpha$ in conferring the modulatory effects of MSC. It was also demonstrated that MSC experience growth arrest in co-culture while modulating microglial responses.

\section{Materials and methods}

Mouse bone marrow mesenchymal stem cell culture

MSC previously isolated from ICR mouse bone marrow were obtained from the culture collection of the Immunology Laboratory, Faculty of Medicine and Health Sciences, Universiti Putra Malaysia. Frozen vials stored in liquid nitrogen were thawed at $37^{\circ} \mathrm{C}$ and cultured in MSC complete medium (high glucose DMEM (GIBCO Invitrogen, CA, USA), supplemented with 15\% (v/v) MesenCult ${ }^{\oplus}$ Mesenchymal Stem Cell Stimulatory Supplements (Mouse) (Stemcell ${ }^{\mathrm{TM}}$ Technologies, Canada), $1 \%$ penicillin and streptomycin (iDNA), $250 \mu \mathrm{g} / \mathrm{ml}$ fungizone (GIBCO Invitrogen, CA, USA), $2.0 \mathrm{mM}$ Gluta$\mathrm{MaX}$ and $1.5 \mathrm{~g}$ sodium bicarbonate) at $37^{\circ} \mathrm{C}, 5 \% \mathrm{CO}_{2}$ in a humidified incubator. Cells were routinely sub-cultured using $0.25 \%$ Trypsin-EDTA (GIBCO Invitrogen, CA, USA) before reaching $90 \%$ confluency and immunophenotyped using a panel of markers comprising CD106, CD45, CD44, CD11b, Sca-1, MHC-I and MHC-II (all from Becton Dickinson, BD, San Jose, CA, USA) [1]. MSC phenotype was confirmed by positivity to CD106, CD44, Sca-1 and MHC-I and negativity to CD45, CD11b and MHC-II.

\section{BV2 microglia culture}

BV2 cells were a generous gift from Dr Thameem Dheen of the National University of Singapore. BV2 is a murine microglial cell line immortalised with v-raf/v-myc genes carrying retrovirus J2 [33]. Cells were cultured in DMEM with $5 \%$ heat-inactivated foetal bovine serum, 100 $\mathrm{U} / \mathrm{ml}$ penicillin, $100 \mu \mathrm{g} / \mathrm{ml}$ streptomycin, $10 \mathrm{~g} / \mathrm{ml}$ gentamicin (all Invitrogen), $1 \times$ non-essential amino acids and $6.25 \mu \mathrm{g} / \mathrm{ml}$ insulin (Sigma-Aldrich, St. Louis, MO, USA). Cells were either sub-cultured or used for downstream assays before reaching $90 \%$ confluency by harvesting with $0.25 \%$ trypsin containing $1 \mathrm{mM}$ EDTA for $5 \mathrm{mi}$ nutes at $37^{\circ} \mathrm{C}$.

\section{MSC/BV2 co-cultures}

BV2 and MSC were seeded simultaneously at a ratio of 1:0.2 and incubated overnight at $37^{\circ} \mathrm{C}$ in a $5 \% \mathrm{CO}_{2}$ incubator to allow cells to adhere. Co-cultures were then stimulated with $1 \mu \mathrm{g} / \mathrm{ml}$ lipopolysaccharide (LPS; E. coli serotype O26:B6; Sigma Cat. No. L2762). This culture setup will be described as 'activated co-cultures' hereafter. The time point of LPS addition was considered as 0 hour for all experiments. Cell culture inserts with a $1 \mu \mathrm{m}$ polyethylene terephthalate membrane pore size (Falcon, BD Biosciences, Erembodegem, Belgium) were used for transwell experiment set-up. 


\section{${ }^{3} \mathrm{H}-\mathrm{TdR}$ incorporation assay}

BV2 cell proliferation was determined by assessing tritiated thymidine ( ${ }^{3} \mathrm{H}-\mathrm{TdR}$; Perkin Elmer, Boston, USA) incorporation. In 96-well plates, $1 \times 10^{3}$ MSC were seeded in triplicate and allowed to adhere overnight. The following day, MSC were treated with $10 \mu \mathrm{g} / \mathrm{ml}$ mitomycin-C (Sigma) for 2 hours to halt their proliferation. Plates were washed thoroughly with DMEM to remove any traces of the mitotic inhibitor and BV2 cells were then seeded at $5 \times 10^{3}$ cells/well. Co-cultures were activated with $1 \mu \mathrm{g} / \mathrm{ml}$ LPS for 48 hours and ${ }^{3} \mathrm{H}-\mathrm{TdR}(0.037 \mathrm{MBq} /$ well $(0.5 \mu \mathrm{Ci} /$ well)) was added to wells at the final 6 hours of incubation. Plates were exposed to a freeze/thaw cycle at $-20^{\circ} \mathrm{C}$ to ease cell harvesting. Cells were harvested onto a filter mat by using an automated cell harvester (Harvester Mach III M, TOMTEC, CT, USA Thymidine incorporation was measured by liquid scintillation spectroscopy on a beta counter (MicroBetaTriLux, Perkin Elmer Boston, USA) after the addition of scintillation fluid (OptiPhaseSuperMix Cocktail; Perkin Elmer Boston, USA) and readouts were in counts per minute (cpm).

\section{Griess assay}

Nitric oxide (NO) was detected in the supernatant of cultures using the Griess assay. For this, $50 \mu$ l culture supernatant from each sample was transferred to a 96-well plate in triplicate and an equal volume of Griess reagent added ( $1 \%$ sulphanilamide/0.1\% N-1-napthylethylenediamine dihydrochloride $/ 2.5 \%$ phosphoric acid; all from Sigma). Absorbance was read at $530 \mathrm{~nm}$ (MRX II microplate reader, Dynex, VA, USA) after 10 minutes incubation. Nitrite concentration was calculated with reference to a standard curve of freshly prepared sodium nitrite $(0$ to $100 \mu \mathrm{M})$. The results are displayed as concentration of $\mathrm{NO}_{2}^{-}$in $\mu \mathrm{M}$.

\section{Apoptosis assay}

Apoptosis of cells in co-culture was determined by flow cytometry after double staining with FITC-Annexin-V and propidium iodide (PI). BV2 cells and MSC were cocultured overnight at a 1:0.2 ratio, stimulated with $1 \mu \mathrm{g} /$ $\mathrm{ml}$ LPS the following day, and left in culture for 48 hours. Cells were then harvested using $0.25 \%$ trypsin-EDTA. Cells were washed twice in ice-cold PBS and suspended in $100 \mu \mathrm{l}$ of $1 \mathrm{X}$ binding buffer at a concentration of $1 \times$ $10^{6}$ cells $/ \mathrm{ml}$. Cells were stained for CD45 by incubating with $0.5 \mu$ antibody (Rat anti-mouse CD45, BioLegend ${ }^{\oplus}$, San Diego, CA, USA ) at $4^{\circ} \mathrm{C}$ for 15 minutes followed by 15 minutes incubation with secondary antibody (DyLight ${ }^{\mathrm{TM}}$ 649 Goat anti-rat IgG, BioLegend ${ }^{\oplus}$ ). CD45 staining was performed to distinguish BV2 microglia from the MSC population during flow cytometry analysis. Five microlitres each of FITC-conjugated Annexin-V and PI was added to each tube and incubated for 15 minutes at room temperature. Four hundred microlitres of $1 \mathrm{X}$ binding buffer was added to each tube before acquisition and analysis using a flow cytometer.

\section{Cell cycle analysis}

Distribution of cells through the three distinct phases of cell cycle (G0/G1, S and G2/M phase) was analysed using PI staining. Co-cultures were harvested using 0.25\% trypsin-EDTA and washed once in PBS by centrifugation at 1,000 rpm for 7 minutes. Cells were then suspended in $1 \mathrm{ml}$ of ice-cold PBS at a density of $0.5 \times 10^{6}$ cells per tube. The cell suspension was subsequently added drop wise to $3 \mathrm{ml}$ ice-cold $95 \%$ ethanol for fixation. The tubes were incubated at $-20^{\circ} \mathrm{C}$ for at least 2 hours. The tubes were removed from $-20^{\circ} \mathrm{C}$ and spun at $1,200 \mathrm{rpm}$ for 10 minutes and washed once using ice-cold PBS to remove traces of ethanol. The cells were then suspended in $500 \mu \mathrm{l}$ of $50 \mu \mathrm{g} /$ $\mathrm{ml}$ PI staining solution and incubated at $37^{\circ} \mathrm{C}$ for $15 \mathrm{mi}-$ nutes. Stained cells were washed once with PBS to remove excess PI and suspended in $400 \mu \mathrm{l}$ PBS. The cell cycle data for individual samples were acquired using the BD LSR Fortessa $^{\text {тм }}$ flow cytometer equipped with BD FACSDiva ${ }^{\text {тм }}$ software (BD) and analysed using ModFit LT $^{\mathrm{TM}}$ software (Verity Software House, ME, USA).

\section{Cytokine bead array/protein array for TNF- $a$ and IL-6 detection}

Co-culture supernatants were assayed at 24 hours using a custom $\mathrm{RayBio}^{\circ}$ mouse cytokine array kit (RayBiotech, Inc., GA, USA ), according to manufacturer's instructions. The results are expressed as relative protein levels compared with LPS-stimulated BV2 cells. Absolute quantity of IL- 6 and TNF- $\alpha$ in culture supernatants were then determined at 24 hours by using a multiplex bead array kit (BD Cytometric Bead Array mouse inflammation kit; BD Biosciences, San Jose, CA, USA), according to the manufacturer's instructions. Samples were assayed on a FACS Fortessa flow cytometer (BD Biosciences) and analysed with FCAP array software (BD Biosciences). Concentration of cytokines in samples was calculated using individual standard curves and expressed as $\mathrm{pg} / \mathrm{ml}$.

\section{Cytokine blocking studies}

Specific blocking antibodies to TNF- $\alpha$ and IL-6 were used to elucidate the functional importance of modulation of these cytokines in co-culture. Blocking antibodies against TNF- $\alpha$ (XT3.11), IL-6 (MP5-20 F3) and isotype (Rat IgG1) control (all from Bio X Cell, NH, USA) were reconstituted in $1 \mathrm{X}$ PBS to $1.0 \mathrm{mg} / \mathrm{ml}$. The antibodies were then serially diluted in culture media to obtain working stock concentrations of 20.0, 2.0 and $0.2 \mu \mathrm{g} / \mathrm{ml}$. Cells were plated either in 12-well plates (for Griess assays) or in 96-well plates (for proliferation assays) as described earlier. Cells were stimulated with $1 \mu \mathrm{g} / \mathrm{ml}$ LPS 
after overnight incubation. Equal volumes of diluted antibody were added to cultures to obtain a final concentration of 10.0, 1.0 and $0.1 \mu \mathrm{g} / \mathrm{ml}$. Culture supernatants were collected at 24 and 48 hours and assayed for $\mathrm{NO}$ production using Griess assay. Proliferation was analysed at 48 hours by pulsing the cultures with ${ }^{3} \mathrm{H}-\mathrm{TdR}$ for the final 6 hours of incubation.

\section{Statistical analysis}

Mean values and standard deviations (SD) were calculated from three independent experiments and significance was assessed using one-way analysis of variance followed by the Tukey post hoc test or student's $t$ test using GraphPad Prism version 6 (GraphPad software, San Diego, CA, USA).

\section{Results}

Mesenchymal stem cells inhibit BV2 microglia proliferation independent of nitric oxide

An in vitro model of microglia proliferation was established by examining BV2 microglia proliferation in response to LPS stimulation at 6, 24 and 48 hours. The proliferation rate of BV2 microglia appeared unaffected by LPS at 6 and 24 hours (Additional file 1: Figure S1a,b). At 48 hours, LPS-stimulated microglia displayed an approximate $30 \%$ increase in proliferation (Figure 1a, $P<0.01$; Additional file 1: Figure S1c). This increase in microglia proliferation was used as a model to test the antiproliferative effect of MSC.

To study the mechanisms through which MSC exert their anti-proliferative effect on microglia, the BV2:MSC ratio of 0.2 was selected based on previous reports from our laboratory [28,34] (see Additional file 2: Figure S2 for images of BV2/MSC co-culture). Co-culturing with MSC at a 0.2 ratio decreased LPS-induced proliferation of BV2 microglia by $28.77 \pm 7.90 \%$ at 48 hours (Figure 1a, $P<0.01$ ), similar to proliferation rates of unstimulated BV2 microglia. MSC were mitotically arrested by mitomycin-C $(10 \mu \mathrm{g} / \mathrm{ml})$ treatment (Additional file 1: Figure S1d,e) to facilitate accurate measurement of microglia proliferation in co-culture.

A previous report from our laboratory demonstrated that MSC generate NO upon exposure to soluble factors from microglia, while BV2/MSC co-culture induces a surge in NO levels beyond that of LPS-stimulated microglia [34]. When tested in this study, co-culture of BV2:MSC at a 1:0.2 ratio induced a 25\% surge in NO levels from $56.94 \pm$ $2.65 \mu \mathrm{M}$ to $76.59 \pm 3.08 \mu \mathrm{M}$ at 48 hours (Figure $1 \mathrm{~b} ; \mathrm{P}<$ $0.01)$. Within an immunomodulatory paradigm, NO has been shown to play a vital role in MSC-mediated suppression of activated $\mathrm{T}$ cell proliferation $[35,36]$. These reports, with the use of MSC derived from inducible nitric oxide synthase $(\mathrm{iNOS})^{-/-}$mice, have pinpointed that NO generated by MSC in the co-culture paradigm plays a vital role in reducing $\mathrm{T}$ cell proliferation. We used $\mathrm{N}$-nitroL-arginine methyl ester (L-NAME), a specific inhibitor of NOS, to address the role of NO in conferring the anti-proliferative effect of MSC on BV2 microglia. We tested a series of L-NAME concentrations (50, 125, 250, 500,750 and $1000 \mu \mathrm{M}$ ) on LPS-stimulated BV2 microglia (Additional file 3: Figure S3) and demonstrated that even reducing the NO levels in co-culture to levels comparable
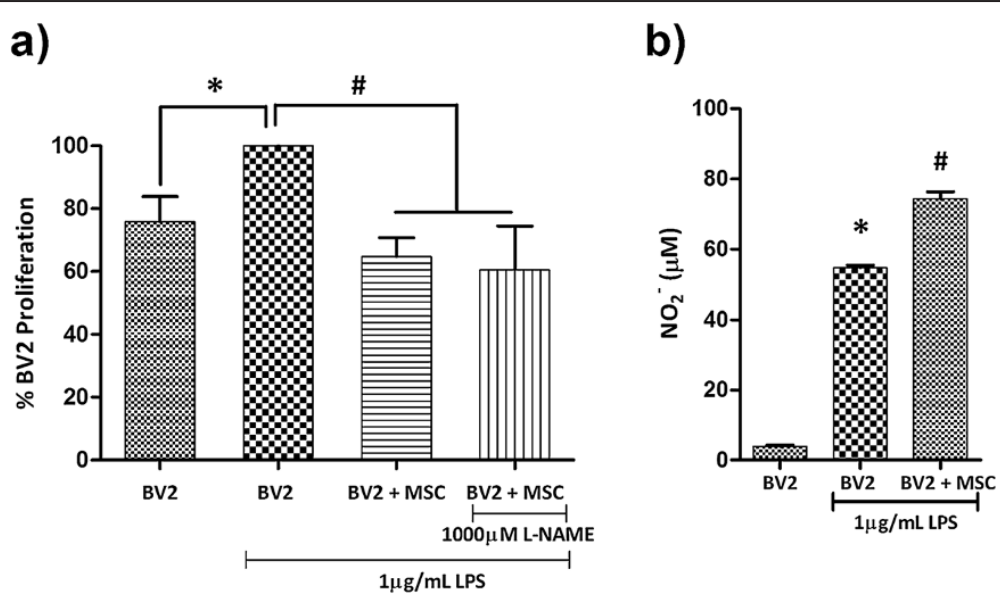

Figure 1 Mesenchymal stem cells inhibits BV2 microglia proliferation independent of nitric oxide. (a) BV2 cells and Mesenchymal stem cells (MSC) were seeded at a 1:0.2 ratio in a 96-well plate with $1 \mu \mathrm{g} / \mathrm{ml}$ lipopolysaccharide (LPS) and $1000 \mu \mathrm{M}$ N-nitro-L-arginine methyl ester (L-NAME) for 48 hours, and BV2 proliferation was determined with a tritiated thymidine ( $\left.{ }^{3} \mathrm{H}-\mathrm{TdR}\right)$ incorporation assay. Values are expressed as mean \pm SD of percentage BV2 proliferation from three independent experiments. (b) $\mathrm{NO}_{2}{ }^{-}$concentration in culture supernatant was determined using the Griess assay. BV2 cells and MSC were cultured in 12-well plates at a 0.2 ratio (BV2: MSC) and stimulated with $1 \mu \mathrm{g} / \mathrm{ml}^{-2} \mathrm{LS}$, and NO${ }_{2}{ }^{-}$was assayed at 48 hours. Values are expressed as mean \pm standard deviation of $\mathrm{NO}_{2}{ }^{-}$in $\mu \mathrm{M}$ from three independent experiments. ${ }^{*} P<0.01$, versus $\mathrm{BV} 2$ cells; \#P<0.01, versus BV2 + LPS. 
to unstimulated BV2 microglia (using $1000 \mu \mathrm{M}$ L-NAME) does not alter the anti-proliferative effect conferred by MSC (Figure 1a).

\section{Co-culture does not induce apoptosis}

Data from the ${ }^{3} \mathrm{H}$-TdR assays indicate that the reduction of microglial proliferation results from a decreased number of actively proliferating cells. Such reductions could also occur due to induced death of the responder cells as reported for MSC-T cell interactions [37], apart from the inhibition of proliferation postulated here. Thus, we sought to determine whether co-culture induces cell death in microglia. When BV2 cells were co-cultured with MSC, the proportion of apoptotic cells as examined by Annexin $\mathrm{V}$ and PI staining (Figure 2a) of the $\mathrm{CD} 45^{+}$population (Additional file 4: Figure S4a,c) was not altered. The average percentage viability (Annexin $-\mathrm{V}^{-} / \mathrm{PI}^{-}$) of BV2 cells remained higher than $94.0 \pm 1.7 \%$ (Additional file 5: Table S1) across all samples tested, ruling out the process of apoptosis as a compounding factor in inhibition of BV2 proliferation by co-culture. Similarly, no significant cell death was noted for MSC (CD45- population; Additional file 4: Figure S4b,c) in co-culture (Figure $2 \mathrm{~b}$ and Additional file 5: Table S1).
Mesenchymal stem cells inhibit BV2 microglia proliferation through contact-dependent cell cycle modulation

MSC in co-culture are shown to induce cell cycle arrest of target cells (splenocytes, dendritic cells and in tumour cells) at G0/G1 phase $[12,14,38]$. Experiments were performed in order to test whether MSC induce similar effects on microglia. At 48 hours, LPS stimulation induced a surge of BV2 microglia in the $\mathrm{S}$ phase of the cell cycle from $40.0 \pm 0.4 \%$ to $57.4 \pm 1.2 \%(P<0.01)$ and direct coculture with MSC reduced the percentage of BV2 microglia in $\mathrm{S}$ phase to $42.7 \pm 1.1(P<0.01)$, levels comparable to resting BV2 cultures (Figure 3a). Experiments were also performed with MSC separated from BV2 cells in culture wells by transwell inserts of $1 \mu \mathrm{m}$ pore size to determine the importance of cell-to-cell contact in cell cycle modulation. The transwell system physically separates BV2 microglia and MSC but permits the transfer of soluble factors and thus enables the demarcation of the role of soluble factors and cell-to-cell contact. MSC in transwell (in the absence of cell-to-cell contact) did not induce a significant change in the percentage population of BV2 cells in S phase $(53.4 \pm 2.4)$ compared with LPS-stimulated BV2 cells, revealing that cell-to-cell contact is critical for MSC-mediated modulation of BV2 microglia cell cycling.

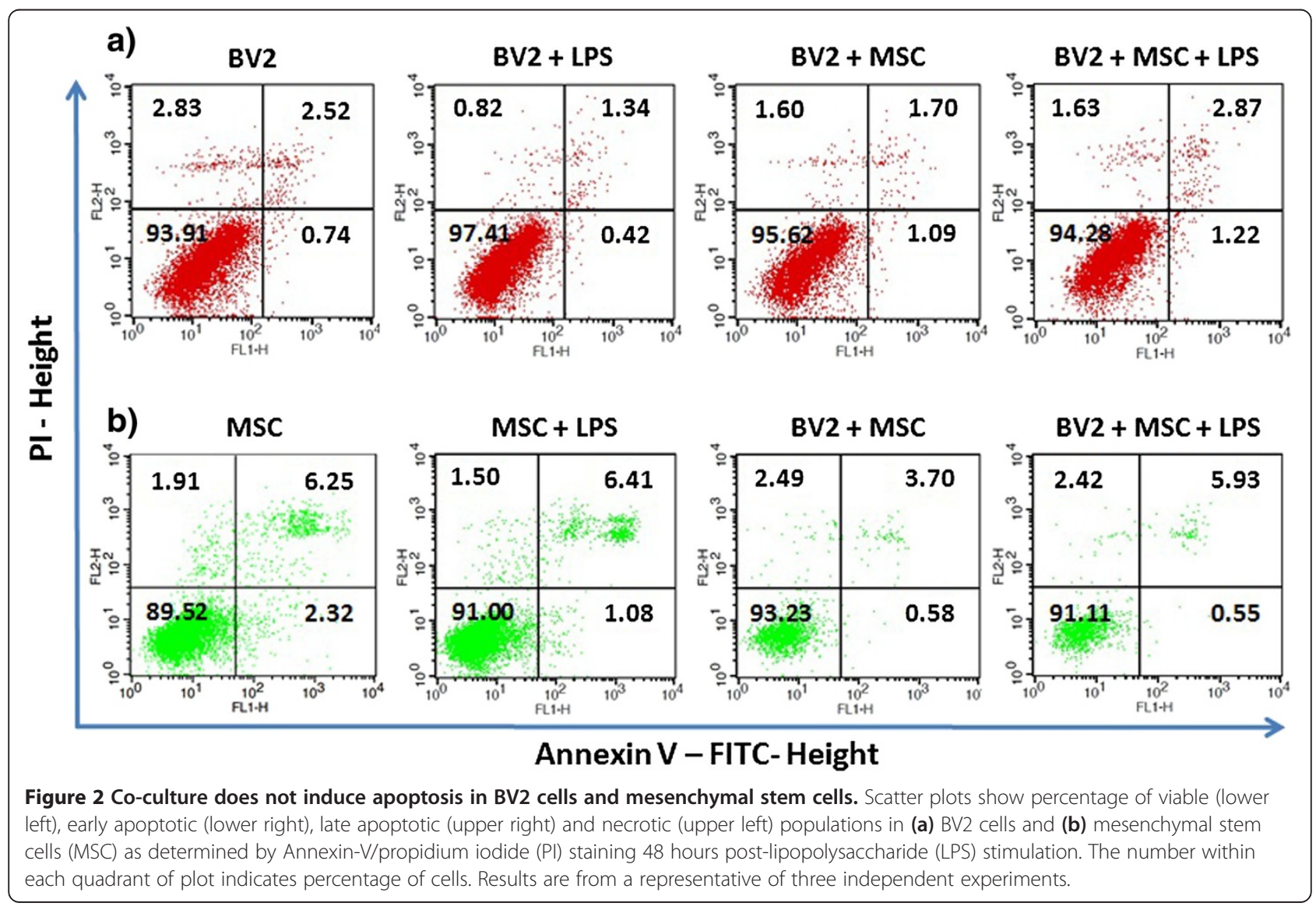


a)

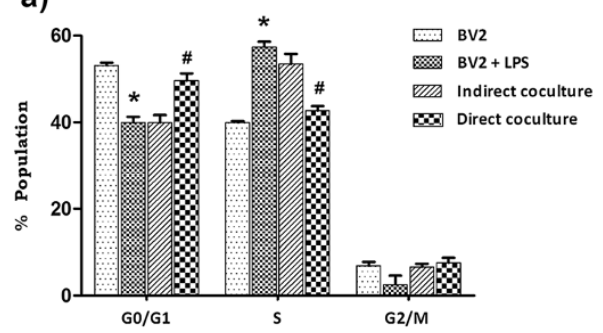

b)

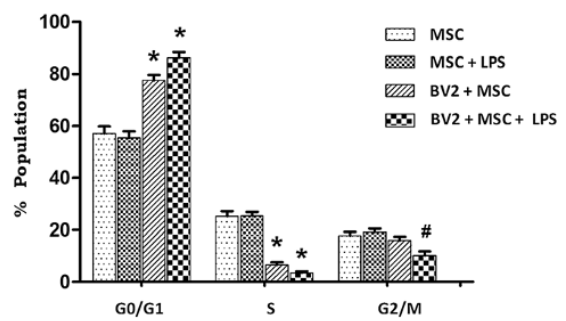

Figure 3 Mesenchymal stem cells inhibit microglia proliferation through contact-dependent cell cycle modulation. BV2 and Mesenchymal stem cells (MSC) were cultured at a 1:0.2 ratio and stimulated with $1 \mu \mathrm{g} / \mathrm{ml}$ lipopolysaccharide (LPS) after overnight incubation. Cells were harvested 48 hours post-LPS stimulation and cell cycle was analysed by propidium iodide staining. Separation of BV2 and MSC populations on flow cytometry was enabled by CD45 staining (see Additional file 3: Figure S3). Histograms show distribution of (a) BV2 cells and (b) MSC from direct co-culture across G0/G1, S and G2/M phases of cell cycle at 48 hours after LPS stimulation and/or co-culture. Values are expressed as mean \pm standard deviation of percentage of cells from three independent experiments. (a) $* P<0.01$, versus BV2 cells; $\# P<0.01$, versus BV2 + LPS. (b) * $P<0.001$, versus MSC; $\# P<0.001$, versus MSC + LPS.

In order to test whether the slowdown of LPS-stimulated BV2 proliferation in co-culture is indeed an arrest, their cell cycle was further analysed at 24, 48, 72 and 96 hours (Table 1) in separate experiments. MSC did not induce cell cycle arrest in BV2 cells at any of the time points tested but continued to restore the cell cycle of LPS-stimulated BV2 microglia to that of resting BV2 cells (BV2 microglia cells alone).

Interestingly, co-culture exerted a G0/G1 arrest in MSC cell cycle by 48 hours. Presence of microglia in the culture induced an approximate $20 \%$ increase of MSC at the G0/G1 phase (Figure 3b; $P<0.001$ ). The surge was more prominent when cultures were stimulated with LPS; LPS-activated microglia retained most of the MSC at G0/G1 phase $(86.32 \pm 2.05 \% ; P<0.001)$. Neither MSC cell cycle (Figure $3 \mathrm{~b}$ ) nor proliferation (Additional file 1: Figure S1f) was affected by exposure to LPS alone. Cell cycle arrest of MSC in co-culture may also be induced by contact inhibition and/or media deprivation. In order to negate these possibilities, the cell seeding density of both MSC and BV2 were reduced by 10 times in coculture and MSC cell cycle was analysed. Even at such low seeding density, where probabilities of contact inhibition or media deprivation was minimal, MSC cell cycle was arrested as early as 24 hours when in co-culture with BV2 microglia (Additional file 6: Figure S5).

\section{Mesenchymal stem cells modulate the cytokine profile of co-cultures}

Culture supernatants were examined using a glass slidebased protein array to identify soluble proteins involved in MSC-mediated immunomodulation of microglia. From this array it was observed that IL- 6 and TNF- $\alpha$ were significantly modulated by co-culture. BV2 microglia in culture produced negligible amounts of IL- 6 and TNF- $\alpha$ (Figure 4a,c). LPS stimulation increased the expression of both cytokines at 24 hours. Co-culture with MSC in the presence of LPS further induced a $25.5 \pm 6.5 \%$ surge in IL6 (Figure 4a, $P<0.001$ ), whilst TNF- $\alpha$ levels were reduced to $33.2 \pm 17.3 \%$ (Figure $4 \mathrm{c}, P<0.001$ ). These cytokines were then quantified using a cytometric bead array. Consistent with the results from protein array, IL-6 production was negligible in BV2 cultures ( $9 \mathrm{pg} / \mathrm{ml}$; Figure $4 \mathrm{~b})$. LPS stimulation increased IL-6 levels to $683.1 \pm 55.4 \mathrm{pg} /$ $\mathrm{ml}$ by 24 hours and the presence of MSC increased IL- 6 levels to $3,693.8 \pm 751.1 \mathrm{pg} / \mathrm{ml}$ in LPS-treated BV2

Table 1 Co-culture with Mesenchymal stem cells continues to modulate BV2 cell cycle until 96 hours but does not induce a cell cycle arrest

\begin{tabular}{|c|c|c|c|c|c|c|c|c|c|}
\hline \multicolumn{10}{|c|}{ Cell cycle distribution (BV2 Microglia: MSC direct coculture) } \\
\hline & \multicolumn{3}{|l|}{ BV2 } & \multicolumn{3}{|l|}{ BV2 + LPS } & \multicolumn{3}{|c|}{$\mathrm{BV} 2+\mathrm{MSC}+\mathrm{LPS}$} \\
\hline & $\overline{\mathrm{G} 0 / \mathrm{G} 1}$ & $\mathbf{S}$ & G2/M & $\overline{\mathrm{G} 0 / \mathrm{G} 1}$ & $\mathrm{~S}$ & G2/M & $\overline{\mathrm{G} 0 / \mathrm{G} 1}$ & $\mathrm{~S}$ & G2/M \\
\hline 24 hrs & $42.8 \pm 1.5$ & $49.3 \pm 3.7$ & $7.0 \pm 2.5$ & $34.2 \pm 0.6^{*}$ & $62.0 \pm 3.8^{\#}$ & $3.8 \pm 3.3$ & $44.3 \pm 1.8^{\dagger}$ & $50.1 \pm 1.0^{\ddagger}$ & $5.6 \pm 4.9$ \\
\hline 48 hrs & $50.7 \pm 1.9$ & $44.2 \pm 1.1$ & $4.7 \pm 1.2$ & $38.2 \pm 1.2^{*}$ & $59.0 \pm 2.7^{\#}$ & $1.8 \pm 2.2$ & $43.9 \pm 1.9^{\dagger}$ & $48.6 \pm 1.2^{\ddagger}$ & $6.3 \pm 3.7$ \\
\hline 72 hrs & $77.6 \pm 0.9$ & $19.3 \pm 0.9$ & $3.1 \pm 0.1$ & $48.2 \pm 1.5^{*}$ & $51.6 \pm 1.8^{\#}$ & $0.3 \pm 0.3$ & $52.4 \pm 5.6$ & $41.3 \pm 2.4^{\ddagger}$ & $1.9 \pm 3.0$ \\
\hline $96 \mathrm{hrs}$ & $83.8 \pm 4.0$ & $14.1 \pm 3.7$ & $2.1 \pm 2.3$ & $63.2 \pm 1.3^{*}$ & $35.7 \pm 21.1^{\#}$ & $1.0 \pm 1.1$ & $75.6 \pm 1.7^{\dagger}$ & $18.4 \pm 0.9^{\ddagger}$ & $6.0 \pm 1.1^{\epsilon}$ \\
\hline
\end{tabular}

BV2 cells and Mesenchymal stem cells (MSC) were seeded at a 1:0.2 ratio in 6-well plates and left overnight prior to lipopolysaccharide (LPS) stimulation (1 $\mu \mathrm{g} / \mathrm{ml})$. Cell cycle analysis of BV2 cells (CD45 + ve population in co-culture) was performed using propidium iodide (PI) staining at the time points indicated. Data show mean percentage population of BV2 cells \pm standard deviation from three independent experiments. ${ }^{*} P<0.05$, ${ }^{\#} P<0.05$, versus respective BV2 alone controls. $\dagger P<0.05, \neq P<0.05$, versus the corresponding phases in BV $2+$ LPS. 


\section{a)}

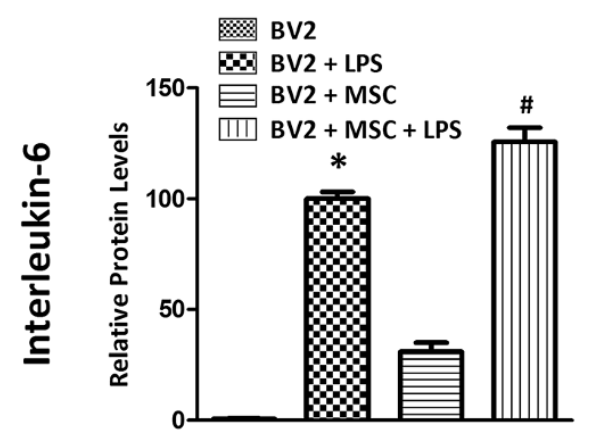

c)

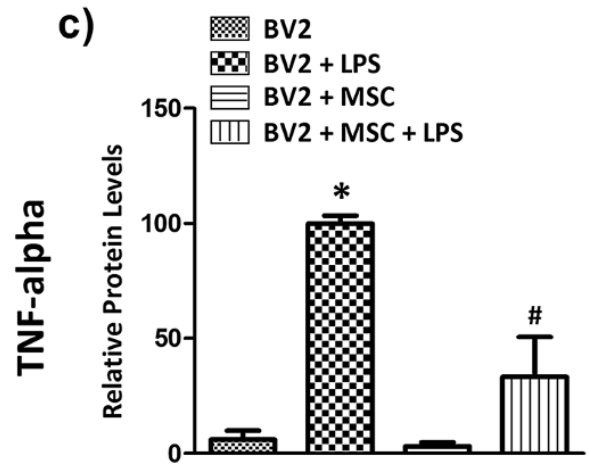

b)

\section{Cytokine Bead Array}

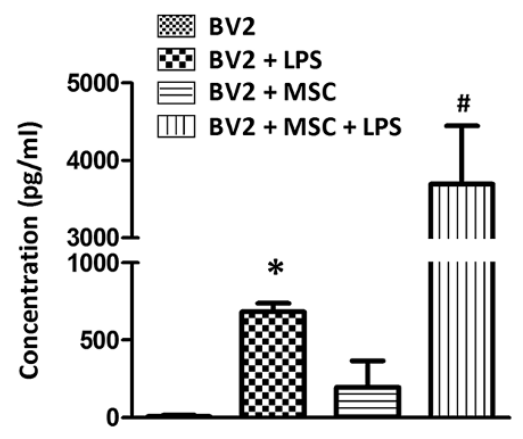

d)

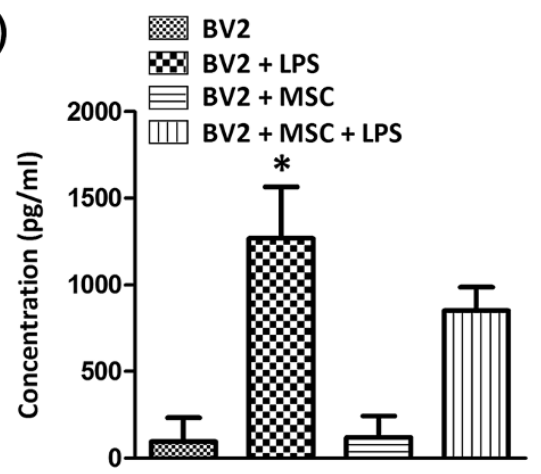

Figure 4 Mesenchymal stem cells modulate the expression of IL- 6 and TNF- $\boldsymbol{a}$ in microglia co-culture. Microglia (BV2 cells or primary microglia) and Mesenchymal stem cells (MSC) were seeded simultaneously into 24-well plates at a 1:0.2 ratio. Cells were left overnight in culture and stimulated with $1 \mathrm{\mu g} / \mathrm{ml}$ lipopolysaccharide (LPS). Culture supernatants were collected 24 hours later and expression of $(\mathbf{a}, \mathbf{b})$ interleukin (IL)-6 and (c,d) tumour necrosis factor (TNF)-a were analysed using the RayBio antibody array (a,c) or BD Cytokine Bead Array (b,d). Protein array results are expressed as mean relative protein level \pm standard deviation from two independent experiments and cytokine bead array results are expressed in mean concentration $(\mathrm{pg} / \mathrm{ml}) \pm$ standard deviation from three independent experiments. ${ }^{*} P<0.001$, versus BV2 cells; $\# P<0.001$, versus BV2 + LPS.
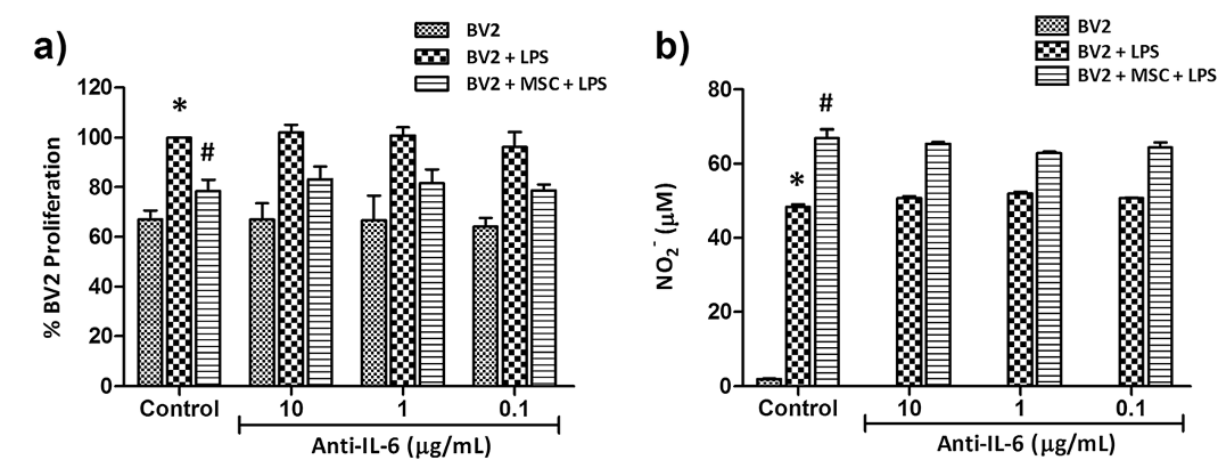

Figure 5 IL-6 does not play a role in mesenchymal stem cell (MSC)-mediated modulation of nitric oxide and proliferation in BV2:MSC co-cultures. BV2 cells and MSC were seeded at a 1:0.2 ratio into 12-well plates (Griess assay) or 96-well plates (proliferation assay). After overnight incubation, $1 \mu \mathrm{g} / \mathrm{ml}$ lipopolysaccharide (LPS) and interleukin (IL)-6 blocking antibodies at concentrations indicated below the graph were added to co-cultures and (a) proliferation and (b) $\mathrm{NO}_{2}{ }^{-}$concentration were analysed at 48 hours. Values are expressed as mean \pm standard deviation from three independent experiments. Controls are respective cultures without blocking antibodies. ${ }^{*} P<0.05$, versus control BV2 cells; $\# P<0.05$, versus control BV2 + LPS. 
microglia cultures (Figure 4b). Conversely the presence of MSC reduced TNF- $\alpha$ levels to $852.1 \pm 134.9 \mathrm{pg} / \mathrm{ml}$ compared with $1,271.2 \pm 294.2 \mathrm{pg} / \mathrm{ml}$ (Figure 4d) in LPS-stimulated BV2 cells alone.

\section{Mesenchymal stem cell-mediated inhibition of microglial proliferation is independent of IL- 6}

LPS stimulation induced proliferation of BV2 microglia by $32.24 \pm 4.5 \%$ and co-culture of BV2 microglia and MSC at the 0.2 ratio reduced LPS-stimulated proliferation of BV2 microglia by $21.50 \pm 3.32 \%$ (Figure $5 \mathrm{a}, P<0.05$ ). In order to identify whether the surge in IL-6 in BV2/MSC co-culture is responsible for the anti-proliferative effect of MSC, IL-6 from cultures was neutralised using anti-mouse IL-6 blocking antibody. An isotype IgG was used as a control to negate any non-specific effects. Addition of isotype IgG did not induce any changes (data not shown). Neutralising IL-6 from cultures did not influence the proliferation of LPS-stimulated microglia nor the anti-proliferative effect of MSC (Figure 5a). It was also demonstrated that IL-6 did not influence the NO production within the MSCmediated immunomodulatory paradigm (Figure 5b).

Mesenchymal stem cells inhibit microglial proliferation by reducing TNF-a

We sought to determine the role of TNF- $\alpha$ in MSCmediated immunomodulation of microglial responses and first addressed whether application of blocking antibodies could affect the NO profile. Similar to that demonstrated previously, co-culture induced a surge in LPS-induced NO production (Figure 6a). Neutralising TNF- $\alpha$ did not affect NO levels in LPS-stimulated BV2 cultures, but $10 \mu \mathrm{g} / \mathrm{ml}$ TNF- $\alpha$ blocking antibody significantly reduced NO levels in co-culture (Figure 6a, $P<$ $0.05)$. Next, we applied recombinant TNF- $\alpha$ to co-cultures and its effect on NO expression was studied. TNF- $\alpha$ levels detected in LPS-stimulated BV2 cultures by the cytokine bead array were approximately $1.5 \mathrm{ng} / \mathrm{ml}$. Addition of
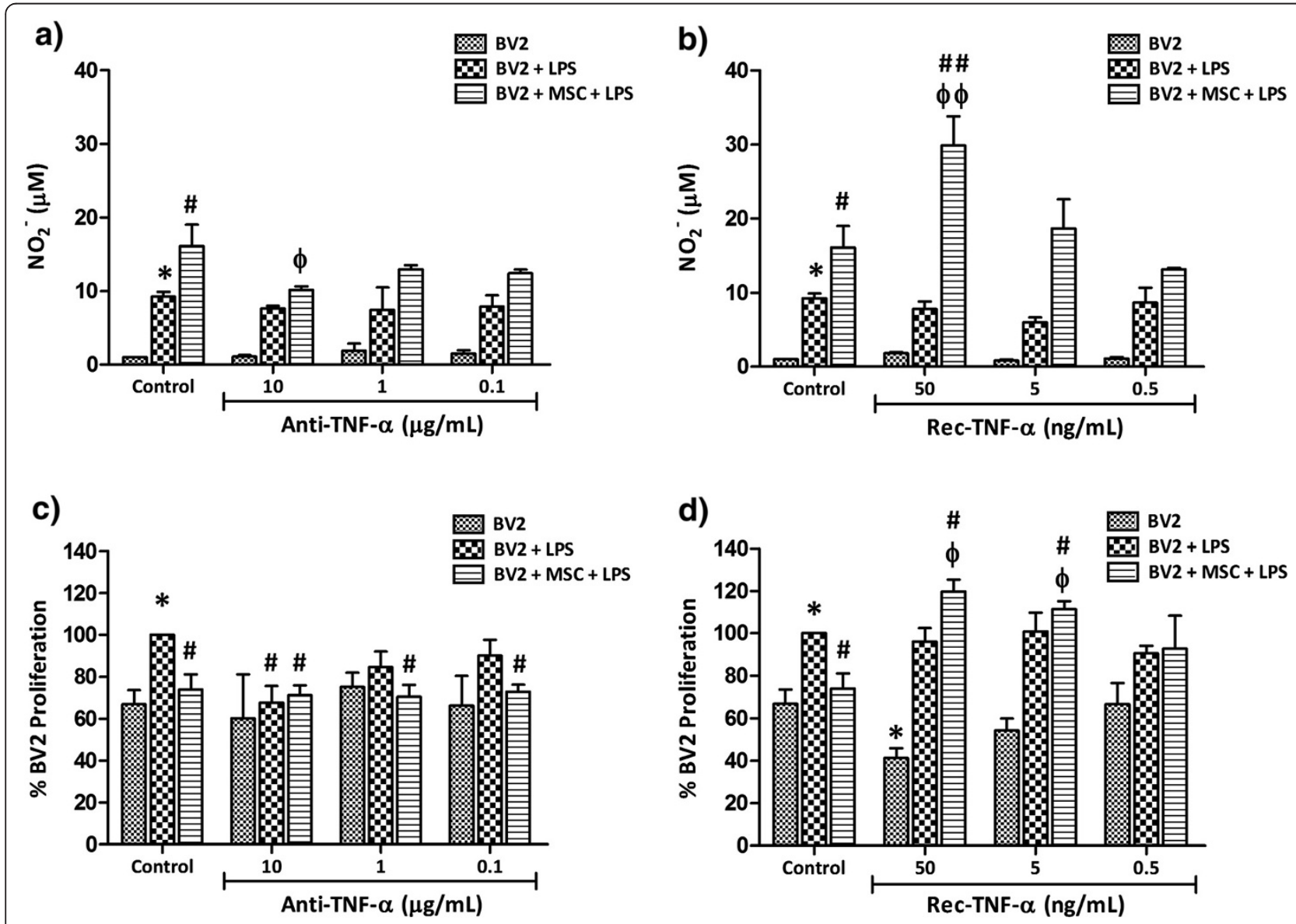

Figure 6 Nitric oxide surge in co-culture and reduction in microglial proliferation are mediated by TNF-a modulation. BV2 cells and mesenchymal stem cells (MSC) were seeded at a 0.2 ratio into 96 well plates. After overnight incubation, 1 mg/ml lipopolysaccharide (LPS) and $(\mathbf{a}, \mathbf{c})$ tumour necrosis factor (TNF)-a blocking antibodies or $(\mathbf{b}, \mathbf{d})$ recombinant TNF-a were added at concentrations indicated below the graph, and $\mathrm{NO}_{2}^{-}$concentration $(a, b)$ and proliferation $(c, d)$ was analysed at 48 hours. Values are expressed as mean \pm standard deviation from three independent experiments. Controls are culture wells without blocking antibodies. ${ }^{*} P<0.05$, versus control BV2 cells; $\# P<0.05$, \#\#P<0.001, versus control BV2 + LPS; $\phi P<0.05, \phi \phi P<0.001$, versus control co-culture + LPS. 
recombinant TNF- $\alpha$ at low concentrations $(0.5$ and $5.0 \mathrm{ng} / \mathrm{ml}$ ) did not affect the NO profile of any of the culture conditions tested (Figure 6b). However, at $50 \mathrm{ng} / \mathrm{ml}$, TNF- $\alpha$ induced NO levels in co-culture by approximately two-fold (Figure 6b, $P<0.001$ compared to activated coculture without recombinant TNF- $\alpha$ ).

Next we sought to address the effect of TNF- $\alpha$ deprivation on microglial proliferation. LPS stimulation induced the proliferation of BV2 microglia by approximately $30 \%$ and in co-culture MSC reduced the proliferation of LPS-stimulated BV2 microglia by $26.13 \pm 7.24 \%$ (Figure 6c, $P<0.05)$. Neutralising TNF- $\alpha$ in LPS-stimulated BV2 microglia cultures (without MSC) reduced their proliferation in a dose-dependent manner; at $10 \mu \mathrm{g} / \mathrm{ml}$, proliferation was reduced to levels similar to unstimulated BV2 microglia. As MSC reduced TNF- $\alpha$ levels (Figure 4c,d) in LPS-stimulated BV2 microglia cultures, we presume that a reduction of TNF- $\alpha$ by MSC may be the mechanism through which MSC exert their anti-proliferative effect on microglia. Further reduction in TNF- $\alpha$ levels did not influence the anti-proliferative effect of MSC; percentage proliferation of BV2 remained between $70.57 \pm 5.6 \%$ and $72.70 \pm 3.5 \%$ for all three antibody concentrations tested (Figure 6c). Addition of recombinant TNF- $\alpha$ to cocultures abolished the anti-proliferative effect of MSC at concentrations as low as $0.5 \mathrm{ng} / \mathrm{ml}$, with higher concentrations inducing a dose-dependent increase in microglial proliferation (Figure $6 \mathrm{~d}$ ). At $50 \mathrm{ng} / \mathrm{ml} \mathrm{TNF}-\alpha$, microglia proliferation was induced in co-culture to $119.75 \pm$ $5.56 \%$ (Figure $6 \mathrm{~d}, P<0.05$ ) compared to $73.87 \pm 7.24 \%$ in the control co-culture.

On the contrary, TNF- $\alpha$ exerted an anti-proliferative effect on resting BV2 microglia (Figure $6 \mathrm{~d}$ ). Addition of TNF- $\alpha$ to unstimulated BV2 culture at $50 \mathrm{ng} / \mathrm{ml}$ reduced their proliferation to $41.26 \pm 4.62 \%$ (Figure $6 \mathrm{~d}, P<0.05$ ) compared to $66.94 \pm 6.58 \%$ in the control, whereas addition of TNF- $\alpha$ did not alter the proliferation of LPS-induced BV2 microglia.

\section{Discussion}

Here, for the first time, we demonstrate the role of TNF- $\alpha$ in MSC-mediated immunomodulation of microglia. Treatment of BV2 microglia cultures with TNF- $\alpha$ blocking antibodies reduced LPS-induced proliferation while addition of recombinant TNF- $\alpha$ to co-cultures abolished the antiproliferative effect of MSC on microglia. Microgliosis is a common response towards injury in the $\mathrm{CNS}$, including Alzheimer's disease [39], Parkinson's disease [40], multiple sclerosis [41] and stroke [42], and the findings here may prove to be beneficial for these conditions.

In addition, the present study negated the role of apoptosis and soluble factors such as NO and IL-6 in conferring this effect. We also provide the first evidence that MSC confer the inhibitory effect on microglia proliferation through modulation of microglia cell cycle and MSC themselves undergo a G0/G1 arrest while exerting this effect.

Following co-culture with MSC, microglia proliferation in response to LPS stimulation was dampened and NO levels were increased. Surge in NO levels in MSC co-cultures have been previously identified as the key mechanism conferring anti-proliferative effects on $\mathrm{T}$ cells $[35,36]$. To examine similar prospects, NO production in co-culture was abolished using a specific iNOS inhibitor L-NAME - and microglia proliferation was analysed. Converse to the reports in MSC/T cell co-cultures, abolishing NO did not restore microglia proliferation in our study. This is contradictory to a recent report which suggested the role of $\mathrm{NO}$ in MSC-mediated inhibition of microglia proliferation [43]. In the mentioned report, conditioned media from MSC cultures treated with an iNOS inhibitor was used to study the anti-proliferative effect, and thus the role of microglial cues that may be required by MSC to exert such effects was not negated. Our laboratory has previously reported that MSC requires microglial cue to induce a NO surge [34]. The current approach to eliminate NO directly from co-culture by addition of L-NAME efficiently negates such doubts and rules out the role of NO in inhibition of microglial proliferation by MSC.

The inhibition of microglial proliferation reported here could also be contributed by cell death. MSC are shown to induce indoleamine 2,3-dioxygenase-dependent apoptosis of activated T cells [37]. Through examination using Annexin-V/PI staining, we demonstrate that co-culture with MSC does not induce apoptosis in microglia. Such differences in interaction of MSC with T cells and microglia emphasises diversity in the modulatory functions that MSC exert on different target cell types.

Next, we examined whether co-culture induces cell cycle modulation in microglia. Studies have shown MSC induce cell cycle arrest in dendritic cells [14] and tumour cells [38]. Here, for the first time, we provide evidence that MSC exert their anti-proliferative effect through modulation of microglia cell cycle. Co-culture with MSC restored the percentage of BV2 cells in the different phases of the cell cycle to levels comparable to resting microglia. Interestingly, this modulation was dependent on cell-to-cell contact. From a therapeutic perspective, we presume that suppression of the proliferative response of microglia through cell cycle modulation is beneficial, as inducing apoptosis or a permanent cell cycle arrest may perturb the volume of glia and hence affect homeostasis of the brain. Interestingly, MSC entered a G0/G1-phase cell cycle arrest while exerting the anti-proliferative effect suggesting that the inhibitory effect of MSC on microglia activation (at least in terms of microglia proliferation) is not dependent on a need for a proliferative response from MSC. The ability of MSC to modulate the proliferative response of microglia whilst simultaneously entering 
a cell cycle arrest is presumably a beneficial one. Tumourigenic transformation of MSC has been implicated in several experimental transplantations including osteogenic sarcomas [44], myocardial infarction and diabetic neuropathy [45]. Therefore, careful evaluation and understanding of proliferative potential of MSC within the inflamed milieu is necessary for the success of clinical interventions.

We have also demonstrated here that MSC modulate the expression of TNF- $\alpha$ and IL-6. Co-culture with MSC significantly reduced the TNF- $\alpha$ which was upregulated upon LPS stimulation whereas co-culture induced a surge in IL-6. Similar modulation of cytokines was also reported previously by us [34] and others [29,43]. The impact of differential modulation of IL- 6 and TNF- $\alpha$ was further deduced using blocking antibodies and recombinant TNF- $\alpha$. Through addition of blocking antibodies, we have identified that the IL-6 surge in co-culture does not influence the anti-proliferative effect of MSC or NO modulation. Distinct from IL-6, TNF- $\alpha$ seems to play a contextdependent role on modulation of $\mathrm{NO}$ and microglial proliferation in co-culture. Reducing TNF- $\alpha$ level in culture using blocking antibodies did not influence the NO profile of activated microglia. However, addition of recombinant TNF- $\alpha$ induced a dose-dependent NO surge in co-cultures. It has been previously described by our group that soluble factors from activated co-culture induce NO production in MSC and these soluble factors include TNF- $\alpha$ [34]. It is possible that, in co-culture, the additional TNF- $\alpha$ added to the co-culture acts in tangent with microglial signals to induce a surge in $\mathrm{NO}$, or TNF- $\alpha$ itself acts as the signal to induce NO production by MSC. MSC are known to respond to TNF- $\alpha$ signals and elicit downstream responses including $\mathrm{NF} \kappa \mathrm{B}$ translocation which is required for iNOS transcription [46]. However, such postulations need to be further validated.

We also showed distinct responses in microglia proliferation upon altering TNF- $\alpha$ levels in culture. TNF- $\alpha$ has been previously identified as vital for beta-amyloid-induced proliferation of microglia; abolishing TNF signals through addition of anti-TNF- $\alpha$ antibody or a soluble TNF receptor inhibitor both prevented beta-amyloid-induced proliferation of microglia [47]. Similarly in an MPTP mouse model of Parkinson's disease, knocking out TNF- $\alpha$ significantly reduced microglial activation as measured by cell number and morphology compared to wild-type controls [48], suggesting the important role played by TNF- $\alpha$ in microglial activation. Managing TNF- $\alpha$ levels in the inflammatory milieu is thus considered an efficient way to modulate inflammation $[48,49]$. At present, there is no evidence to suggest that modulation of TNF- $\alpha$ is the mechanism through which MSC confer an anti-proliferative effect on microglia. Likewise, there is no report on how MSC reduce microglial TNF- $\alpha$. However, earlier reports from our laboratory [34] and the present study confirms the potential of MSC to downregulate TNF- $\alpha$ production in an LPS-stimulated microglia co-culture paradigm. Similarly, intravenous transplantation of MSC into rat traumatic brain injury models significantly decreased TNF- $\alpha$ levels in the injured cortex and decreased the number of glial cells at the site of injury [50]. Thus, we hypothesised that modulation of TNF- $\alpha$ by MSC may be vital in conferring their anti-proliferative effect and monitored the effects of neutralising TNF- $\alpha$ and adding recombinant TNF- $\alpha$ on proliferation of LPS-stimulated BV2 microglia in co-culture. Abolishing TNF- $\alpha$ from co-culture did not enhance the anti-proliferative effect of MSC, indicating that a further decrease of TNF- $\alpha$ from that seen in co-cultures does not have an additive effect on MSC anti-proliferation of BV2. Also, the basal proliferation of BV2 cells may not require TNF- $\alpha$, as addition of anti-TNF onto unstimulated BV2 did not affect their proliferation. However, the proliferation of LPS-stimulated microglia was reduced in a dosedependent manner upon addition of TNF- $\alpha$ neutralising antibodies, thus confirming the role of TNF- $\alpha$ in inducing proliferation of microglia. It is noteworthy that addition of recombinant TNF- $\alpha$ to LPS-stimulated BV2 culture did not increase their proliferation. This indicates that a critical concentration of TNF- $\alpha$ may be required for microglial activation above which the cells may become non-responsive. Also, other cues may be necessary for a proliferative response. Considering the requirement of cellto-cell contact in modulating the cell cycle of activated microglia, we suggest the involvement of one or few cell surface molecules that may work in tandem with TNF- $\alpha$ modulation to achieve the inhibition of microglia proliferation by MSC. Recent studies have strongly suggested the role of cell surface molecules such as CD200 [51], HLA-G [52] and PD-1 [53] expressed by MSC on their immunomodulatory potential. It is possible that these cell surface ligands could be involved in the MSC-mediated modulation of BV2 microglia proliferation.

Next, in order to confirm the relation of MSC-mediated reduction of TNF- $\alpha$ and inhibition of microglial proliferation in co-culture, we used recombinant TNF- $\alpha$. At concentrations as low as $0.5 \mathrm{ng} / \mathrm{ml}$, TNF- $\alpha$ abolished the inhibition of microglia proliferation in co-culture. Moreover, higher concentrations of recombinant TNF- $\alpha$ induced the proliferation of microglia in co-culture to levels beyond that of LPS-stimulated culture. This confirms downregulation of TNF- $\alpha$ in co-culture by MSC as the key mechanism leading to the inhibition of microglial proliferation.

\section{Conclusions}

Our results demonstrate the role of TNF- $\alpha$ in MSCmediated immunomodulation of microglia. In addition, the present study negated the role of apoptosis and the 
soluble factors NO and IL-6 in conferring MSC-mediated inhibition of microglia proliferation. We also provide evidence that MSC confer the inhibitory effect on microglia proliferation through modulation of microglia cell cycle and MSC themselves undergo a G0/G1 arrest while exerting this effect. These findings suggest the potential use of MSC in modulating microglial responses in inflammatory conditions.

\section{Additional files}

Additional file 1: Figure S1. Effect of LPS on BV2 and MSC cell proliferation and mitomycin-C on MSC. MSCS and BV2 microglia were co-cultured at a 1:0.2 ratio and proliferation was analysed with ${ }^{3} \mathrm{H}-\mathrm{TdR}$ incorporation at (a) 6 hours, (b) 24 hours and (c) 48 hours after stimulation with $1 \mu \mathrm{g} / \mathrm{ml}$ LPS. MSC were cultured independently at the same seeding density and treated with $10 \mu \mathrm{g} / \mathrm{ml}$ mit-C for 2 hours after overnight culture. (d) Proliferation and (e) cell cycle was analysed 48 hours post mit-C treatment with ${ }^{3} \mathrm{H}-\mathrm{TdR}$ incorporation and PI staining respectively. (f) MSC culture was stimulated with $1 \mu \mathrm{g} / \mathrm{ml}$ LPS and proliferation was analysed with ${ }^{3} \mathrm{H}-\mathrm{TdR}$ incorporation at 48 hours post-LPS stimulation. Values are expressed as mean \pm SD from three independent experiments. ${ }^{*} P<0.05$, versus respective controls. ${ }^{3} \mathrm{H}-\mathrm{TdR}$, tritiated thymidine; LPS, lipopolysaccharide; mit-C, mitomycin C; MSC, mesenchymal stem cells; PI, propidium iodide; SD, standard deviation.

Additional file 2: Figure S2. Morphology of BV2 cells and MSC in culture. Phase contrast images showing morphology of BV2 cells and MSC seeded at a 1:0.2 ratio in a 6-well plate with $1 \mu \mathrm{g} / \mathrm{ml}$ LPS at 48 hours. LPS, lipopolysaccharide; MSC, mesenchymal stem cells.

Additional file 3: Figure S3. L-NAME inhibits NO in a dose dependent manner. $\mathrm{NO}_{2}^{-}$concentration in culture supernatant was determined using the Griess assay at 24 and 48 hours. BV2 cells were stimulated with $1 \mu \mathrm{g} /$ $\mathrm{ml}$ LPS in the presence of different concentrations of L-NAME as indicated below the graph and NO was assayed. Values are expressed as mean $\pm S D$ of three independent experiments. ${ }^{*} P<0.01$, versus BV2 cells; $\# P<0.01$, versus BV2 + LPS. LPS, lipopolysaccharide; L-NAME, N-nitro-L-arginine methyl ester; NO, nitric oxide; SD, standard deviation.

Additional file 4: Figure S4. BV2 microglia and MSC show distinct CD45 expression. Scatter plots show CD45 expression of (a) BV2 microglia, (b) MSC and (c) co-culture after 48 hours in culture. (d) Distribution of viable (lower left), early apoptotic (lower right), late apoptotic (upper right) and necrotic (upper left) population in DMSO treated BV2 cells (positive control for apoptosis assay) as determined by Annexin-V/PI staining. Numbers within each quadrant of plot indicate percentage of cells. Results are from a representative of three independent experiments. MSC, mesenchymal stem cells; PI, propidium iodide.

Additional file 5: Table S1. Co-culture does not induce apoptosis in BV2 cells and MSC. Table shows apoptosis assay results of BV2 microglia and MSC at 48 hours after co-culture. Results are expressed as mean \pm SD from three independent experiments. BV2, BV2 microglia; LPS, lipopolysaccharide; MSC, mesenchymal stem cells; SD, standard deviation.

Additional file 6: Figure S5. Microglia-induced cell cycle arrest of MSC is not because of contact inhibition or nutrient deprivation. BV2 and MSC were co-cultured at a 1:0.2 ratio at a seeding density 10-fold lower than usual and were stimulated with $1 \mathrm{\mu g} / \mathrm{ml}$ LPS after overnight incubation. Cells were harvested 48 hours post-LPS stimulation and cell cycle was analysed by propidium iodide staining. Separation of BV2 and MSC populations on flow cytometry was enabled by CD45 staining. LPS, lipopolysaccharide; MSC, mesenchymal stem cells.

\section{Abbreviations}

CNS: central nervous system; DMEM: Dulbecco's modified Eagle's medium; ${ }^{3} \mathrm{H}-\mathrm{TdR}$ : tritiated thymidine; Ig: immunoglobulin; IL: interleukin; iNOS: inducible nitric oxide synthase; L-NAME: N-nitro-L-arginine methyl ester; LPS: lipopolysaccharide; MSC: mesenchymal stem cells; NO: nitric oxide;
PBS: phosphate-buffered saline; PI: propidium iodide; TNF: tumour necrosis factor.

\section{Competing interests}

The authors declare that they have no competing interests.

\section{Authors' contributions}

SJ designed and conducted the experiments, analysed the data and wrote the manuscript. SWT performed the Griess assays. YYO performed the cytometric bead array. RR assessed the cell cycle data. SV conceived and designed the study, obtained funding for the work, and analysed the data. All authors read and approved the final.

\section{Acknowledgements}

We thank Tong Chih Kong for his assistance with the apoptosis assay, Catherine Chieng Cheng Yun for discussions and critical comments on the manuscript, and Marsitah Abdul Jalil for maintaining the flow cytometer facility. This study was funded by the ScienceFund (Ministry of Science, Technology and Innovation, Malaysia) [02-01-04-SF1538] and Exploratory Research Grant Scheme (Ministry of Higher Education, Malaysia) [ERGS/1/2012/5527106].

\section{Author details}

${ }^{1}$ Neuroinflammation Group, Immunology Laboratory, Department of Pathology, Faculty of Medicine and Health Sciences, Universiti Putra Malaysia, 43400 Serdang, Selangor, Malaysia. ${ }^{2}$ Genetic Medicine Research Centre, Faculty of Medicine and Health Sciences, Universiti Putra Malaysia, 43400 Serdang, Selangor, Malaysia. ${ }^{3}$ Current address: Tissue Engineering Centre, Universiti Kebangsaan Malaysia Medical Centre, 56000 Kuala Lumpur, Malaysia. ${ }^{4}$ Department of Anatomy, Yong Loo Lin School of Medicine, NUS, MD10, 4 Medical Drive, Singapore 117597, Singapore. ${ }^{5}$ Stem Cells \& Immunity Group, Immunology Laboratory, Department of Pathology, Faculty of Medicine and Health Sciences, Universiti Putra Malaysia, 43400 Serdang, Selangor, Malaysia.

Received: 19 May 2014 Accepted: 9 August 2014

Published: 3 September 2014

\section{References}

1. Ooi YY, Rahmat Z, Jose S, Ramasamy R, Vidyadaran S: Immunophenotype and differentiation capacity of bone marrow-derived mesenchymal stem cells from CBA/Ca, ICR and Balb/c mice. World I Stem Cells 2013, 5:34-42.

2. Uccelli A, Moretta L, Pistoia V: Mesenchymal stem cells in health and disease. Nat Rev Immunol 2008, 8:726-736.

3. Le Blanc K, Frassoni F, Ball L, Locatelli F, Roelofs H, Lewis I, Lanino E, Sundberg B, Bernardo ME, Remberger M, Dini G, Egeler RM, Bacigalupo A, Fibbe W, Ringden O: Mesenchymal stem cells for treatment of steroid-resistant, severe, acute graft-versus-host disease: a phase II study. Lancet 2008, 371:1579-1586.

4. Fisher-Shoval Y, Barhum Y, Sadan O, Yust-Katz S, Ben-Zur T, Lev N, Benkler C, Hod M, Melamed E, Offen D: Transplantation of placenta-derived mesenchymal stem cells in the EAE mouse model of MS. J Mol Neurosci 2012, 48:176-184.

5. Gutierrez-Fernandez M, Rodriguez-Frutos B, Ramos-Cejudo J, Teresa VallejoCremades M, Fuentes B, Cerdan S, Diez-Tejedor E: Effects of intravenous administration of allogenic bone marrow- and adipose tissue-derived mesenchymal stem cells on functional recovery and brain repair markers in experimental ischemic stroke. Stem Cell Res Ther 2013, 4:11.

6. Boucherie C, Schafer S, Lavand'homme P, Maloteaux JM, Hermans E: Chimerization of astroglial population in the lumbar spinal cord after mesenchymal stem cell transplantation prolongs survival in a rat model of amyotrophic lateral sclerosis. J Neurosci Res 2009, 87:2034-2046.

7. Abrams MB, Dominguez C, Pernold K, Reger R, Wiesenfeld-Hallin Z, Olson L, Prockop D: Multipotent mesenchymal stromal cells attenuate chronic inflammation and injury-induced sensitivity to mechanical stimuli in experimental spinal cord injury. Restor Neurol Neurosci 2009, 27:307-321.

8. Pileggi A: Mesenchymal stem cells for the treatment of diabetes. Diabetes 2012, 61:1355-1356.

9. Alfaro MP, Pagni M, Vincent A, Atkinson J, Hill MF, Cates J, Davidson JM, Rottman J, Lee E, Young PP: The Wnt modulator sFRP2 enhances mesenchymal stem cell engraftment, granulation tissue formation and myocardial repair. Proc Natl Acad Sci U S A 2008, 105:18366-18371. 
10. Krampera M, Glennie S, Dyson J, Scott D, Laylor R, Simpson E, Dazzi F: Bone marrow mesenchymal stem cells inhibit the response of naive and memory antigen-specific T cells to their cognate peptide. Blood 2003, 101:3722-3729.

11. Corcione A, Benvenuto F, Ferretti E, Giunti D, Cappiello V, Cazzanti F, Risso M, Gualandi F, Mancardi GL, Pistoia V, Uccelli A: Human mesenchymal stem cells modulate B-cell functions. Blood 2006, 107:367-372.

12. Glennie S, Soeiro I, Dyson PJ, Lam EW, Dazzi F: Bone marrow mesenchymal stem cells induce division arrest anergy of activated T cells. Blood 2005, 105:2821-2827.

13. Jiang XX, Zhang Y, Liu B, Zhang SX, Wu Y, Yu XD, Mao N: Human mesenchymal stem cells inhibit differentiation and function of monocyte-derived dendritic cells. Blood 2005, 105:4120-4126.

14. Ramasamy R, Fazekasova H, Lam EW, Soeiro I, Lombardi G, Dazzi F: Mesenchymal stem cells inhibit dendritic cell differentiation and function by preventing entry into the cell cycle. Transplantation 2007, 83:71-76.

15. English K, Barry FP, Mahon BP: Murine mesenchymal stem cells suppress dendritic cell migration, maturation and antigen presentation. Immunol Lett 2008, 115:50-58.

16. Ginhoux F, Greter M, Leboeuf M, Nandi S, See P, Gokhan S, Mehler MF, Conway SJ, Ng LG, Stanley ER, Samokhvalov IM, Merad M: Fate mapping analysis reveals that adult microglia derive from primitive macrophages. Science 2010, 330:841-845.

17. Hughes V: Microglia: the constant gardeners. Nature 2012, 485:570-572.

18. Hanisch UK, Kettenmann H: Microglia: active sensor and versatile effector cells in the normal and pathologic brain. Nat Neurosci 2007, 10:1387-1394.

19. Schafer DP, Lehrman EK, Kautzman AG, Koyama R, Mardinly AR, Yamasaki R, Ransohoff RM, Greenberg ME, Barres BA, Stevens B: Microglia sculpt postnatal neural circuits in an activity and complement-dependent manner. Neuron 2012, 74:691-705.

20. Tremblay ME, Lowery RL, Majewska AK: Microglial interactions with synapses are modulated by visual experience. PLoS Biol 2010, 8:e1000527.

21. Nimmerjahn A, Kirchhoff F, Helmchen F: Resting microglial cells are highly dynamic surveillants of brain parenchyma in vivo. Science 2005, 308:1314-1318.

22. Aguzzi A, Barres BA, Bennett ML: Microglia: scapegoat, saboteur, or something else? Science 2013, 339:156-161.

23. Gomes C, Ferreira R, George J, Sanches R, Rodrigues DI, Goncalves N, Cunha RA: Activation of microglial cells triggers a release of brain-derived neurotrophic factor (BDNF) inducing their proliferation in an adenosine $A 2 A$ receptor-dependent manner: $A 2 A$ receptor blockade prevents BDNF release and proliferation of microglia. J Neuroinflammation 2013, 10:16.

24. Burguillos MA, Deierborg T, Kavanagh E, Persson A, Hajji N, Garcia-Quintanilla A, Cano J, Brundin P, Englund E, Venero JL, Joseph B: Caspase signalling controls microglia activation and neurotoxicity. Nature 2011, 472:319-324.

25. Ghoshal A, Das S, Ghosh S, Mishra MK, Sharma V, Koli P, Sen E, Basu A: Proinflammatory mediators released by activated microglia induces neuronal death in Japanese encephalitis. Glia 2007, 55:483-496.

26. Wu DC, Jackson-Lewis V, Vila M, Tieu K, Teismann P, Vadseth C, Choi DK, Ischiropoulos H, Przedborski S: Blockade of microglial activation is neuroprotective in the 1-methyl-4-phenyl-1,2,3,6-tetrahydropyridine mouse model of Parkinson disease. J Neurosci 2002, 22:1763-1771.

27. Saijo K, Crotti A, Glass CK: Regulation of microglia activation and deactivation by nuclear receptors. Glia 2013, 61:104-111.

28. Ooi YY, Ramasamy R, Rahmat Z, Subramaiam H, Tan SW, Abdullah M, Israf DA, Vidyadaran S: Bone marrow-derived mesenchymal stem cells modulate BV2 microglia responses to lipopolysaccharide. Int Immunopharmacol 2010, 10:1532-1540.

29. Zhou C, Zhang C, Chi S, Xu Y, Teng J, Wang H, Song Y, Zhao R: Effects of human marrow stromal cells on activation of microglial cells and production of inflammatory factors induced by lipopolysaccharide. Brain Res 2009, 1269:23-30.

30. Lanza C, Morando S, Voci A, Canesi L, Principato MC, Serpero LD, Mancardi G, Uccelli A, Vergani L: Neuroprotective mesenchymal stem cells are endowed with a potent antioxidant effect in vivo. J Neurochem 2009, 110:1674-1684.

31. Lee JK, Jin HK, Bae JS: Bone marrow-derived mesenchymal stem cells reduce brain amyloid-beta deposition and accelerate the activation of microglia in an acutely induced Alzheimer's disease mouse model. Neurosci Lett 2009, 450:136-141.

32. Kim JY, Kim DH, Kim JH, Lee D, Jeon HB, Kwon SJ, Kim SM, Yoo YJ, Lee EH, Choi SJ, Seo SW, Lee Jl, Na DL, Yang YS, Oh W, Chang JW: Soluble intracellular adhesion molecule-1 secreted by human umbilical cord blood-derived mesenchymal stem cell reduces amyloid-beta plaques. Cell Death Differ 2012, 19:680-691.

33. Blasi E, Barluzzi R, Bocchini V, Mazzolla R, Bistoni F: Immortalization of murine microglial cells by a v-raf/v-myc carrying retrovirus. J Neuroimmunol 1990, 27:229-237.

34. Rahmat Z, Jose $S$, Ramasamy R, Vidyadaran S: Reciprocal interactions of mouse bone marrow-derived mesenchymal stem cells and BV2 microglia following lipopolysaccharide stimulation. Stem Cell Res Ther 2013, 4:12.

35. Ren G, Zhang L, Zhao X, Xu G, Zhang Y, Roberts Al, Zhao RC, Shi Y: Mesenchymal stem cell-mediated immunosuppression occurs via concerted action of chemokines and nitric oxide. Cell Stem Cell 2008, 2:141-150.

36. Sato K, Ozaki K, Oh I, Meguro A, Hatanaka K, Nagai T, Muroi K, Ozawa K: Nitric oxide plays a critical role in suppression of T-cell proliferation by mesenchymal stem cells. Blood 2007, 109:228-234.

37. Plumas J, Chaperot L, Richard MJ, Molens JP, Bensa JC, Favrot MC: Mesenchymal stem cells induce apoptosis of activated T cells. Leukemia 2005, 19:1597-1604.

38. Ramasamy R, Lam EW, Soeiro I, Tisato V, Bonnet D, Dazzi F: Mesenchymal stem cells inhibit proliferation and apoptosis of tumor cells: impact on in vivo tumor growth. Leukemia 2007, 21:304-310.

39. Block ML, Zecca L, Hong JS: Microglia-mediated neurotoxicity: uncovering the molecular mechanisms. Nat Rev Neurosci 2007, 8:57-69.

40. Vroon A, Drukarch B, Bol JG, Cras P, Breve JJ, Allan SM, Relton JK, Hoogland PV, Van Dam AM: Neuroinflammation in Parkinson's patients and MPTP-treated mice is not restricted to the nigrostriatal system: microgliosis and differential expression of interleukin-1 receptors in the olfactory bulb. Exp Gerontol 2007, 42:762-771.

41. Groebe A, Clarner T, Baumgartner W, Dang J, Beyer C, Kipp M: Cuprizone treatment induces distinct demyelination, astrocytosis, and microglia cell invasion or proliferation in the mouse cerebellum. Cerebellum 2009, 8:163-174.

42. Li T, Pang S, Yu Y, Wu X, Guo J, Zhang S: Proliferation of parenchymal microglia is the main source of microgliosis after ischaemic stroke. Brain 2013, 136:3578-3588.

43. Yan $K$, Zhang $R$, Sun C, Chen L, Li P, Liu Y, Peng L, Sun H, Qin K, Chen F, Huang W, Chen Y, Lv B, Du M, Zou Y, Cai Y, Qin L, Tang Y, Jiang X: Bone marrow-derived mesenchymal stem cells maintain the resting phenotype of microglia and inhibit microglial activation. PLOS One 2013 8:e84116.

44. Tolar J, Nauta AJ, Osborn MJ, Panoskaltsis Mortari A, McElmurry RT, Bell S, Xia L, Zhou N, Riddle M, Schroeder TM, Westendorf JJ, Mclvor RS, Hogendoorn PC, Szuhai K, Oseth L, Hirsch B, Yant SR, Kay MA, Peister A, Prockop DJ, Fibbe WE, Blazar BR: Sarcoma derived from cultured mesenchymal stem cells. Stem Cells 2007, 25:371-379.

45. Jeong JO, Han JW, Kim JM, Cho HJ, Park C, Lee N, Kim DW, Yoon YS: Malignant tumor formation after transplantation of short-term cultured bone marrow mesenchymal stem cells in experimental myocardial infarction and diabetic neuropathy. Circ Res 2011, 108:1340-1347.

46. van den Berk LC, Jansen BJ, Siebers-Vermeulen KG, Roelofs H, Figdor CG, Adema GJ, Torensma R: Mesenchymal stem cells respond to TNF but do not produce TNF. J Leukoc Biol 2010, 87:283-289.

47. Jekabsone A, Mander PK, Tickler A, Sharpe M, Brown GC: Fibrillar beta-amyloid peptide Abeta 1-40 activates microglial proliferation via stimulating TNF-alpha release and $\mathrm{H} 2 \mathrm{O} 2$ derived from NADPH oxidase: a cell culture study. J Neuroinflammation 2006, 3:24.

48. Barcia C, Ros CM, Annese V, Gomez A, Ros-Bernal F, Aguado-Yera D, Martinez-Pagan ME, de Pablos V, Fernandez-Villalba E, Herrero MT: IFN-gamma signaling, with the synergistic contribution of TNF-alpha, mediates cell specific microglial and astroglial activation in experimental models of Parkinson's disease. Cell Death Dis 2011, 2:e142.

49. Ferger B, Leng A, Mura A, Hengerer B, Feldon J: Genetic ablation of tumor necrosis factor-alpha (TNF-alpha) and pharmacological inhibition of TNF-synthesis attenuates MPTP toxicity in mouse striatum. $J$ Neurochem 2004, 89:822-833.

50. Zhang R, Liu Y, Yan K, Chen L, Chen XR, Li P, Chen FF, Jiang XD: Anti-inflammatory and immunomodulatory mechanisms of 
mesenchymal stem cell transplantation in experimental traumatic brain injury. J Neuroinflammation 2013, 10:106.

51. Najar M, Raicevic G, Jebbawi F, De Bruyn C, Meuleman N, Bron D, Toungouz M, Lagneaux L: Characterization and functionality of the CD200-CD200R system during mesenchymal stromal cell interactions with T-lymphocytes. Immunol Lett 2012, 146:50-56.

52. Nasef A, Mathieu N, Chapel A, Frick J, Francois S, Mazurier C, Boutarfa A, Bouchet S, Gorin NC, Thierry D, Fouillard L: Immunosuppressive effects of mesenchymal stem cells: involvement of HLA-G. Transplantation 2007, 84:231-237.

53. Luz-Crawford P, Noel D, Fernandez X, Khoury M, Figueroa F, Carrion F, Jorgensen C, Djouad F: Mesenchymal stem cells repress Th17 molecular program through the PD-1 pathway. PLoS One 2012, 7:e45272.

doi:10.1186/s12974-014-0149-8

Cite this article as: Jose et al:: Mesenchymal stem cells exert anti-proliferative effect on lipopolysaccharide-stimulated BV2 microglia by reducing tumour necrosis factor-a levels. Journal of Neuroinflammation 2014 11:149.

\section{Submit your next manuscript to BioMed Central and take full advantage of:}

- Convenient online submission

- Thorough peer review

- No space constraints or color figure charges

- Immediate publication on acceptance

- Inclusion in PubMed, CAS, Scopus and Google Scholar

- Research which is freely available for redistribution 